\title{
The Role of Selected salient attributes on Customer Satisfaction in Hotel Industry; A Case Study of Mbeya City Hotels
}

\author{
William L. Mboma, Doreen Ngaiza, Beatrice G. Yamlinga, Bundala M. Kate
}

\begin{abstract}
The aim of this research paper was to assess the role of selected salient attributes on the customer satisfaction in the hotel sectors the case being Mbeya city Hotels. The specific objectives of this study included the attributes of customer relationship management on service quality, customer satisfaction and customer loyalty in Hotel industry and the service quality dimensions which relate to customer satisfaction. Several methods were used in the data collection. These methods were survey, questionnaire, interview and physical visits. A total of 55 of respondents were sampled and used among the customers and hotel owners. Data were analyzed using SPSS software. The study found out that about $2(40 \%)$ of the respondents (hotel owners) identified revenue growth (profit) and number of customers as the main indicators that measures business performance in the field. About $22(44 \%)$ out of 50 customers identified number of customers, $16(32 \%)$ identified revenue growth and $6(12 \%)$ identified employee satisfaction as key indicators that measures business performance in the study area. As per communication to the customers concerned on the attributes of customer relationship on customer satisfaction, the findings showed $20(40 \%)$ of the customers identified customer satisfaction, $15(30 \%)$ identified customer loyalty and $7(14 \%)$ identified communication to customers as key attributes and $2(40 \%)$ of hotel owners identified customer satisfaction and customer loyalty respectively as the key attributes of customer relationship management on service in Hotel Industry. The study recommended that hotel owners and employee should make their visitors happy and satisfied, hotel management should focus on the main factors that contribute towards customer satisfaction and also hotels should understand the needs of the customer and provide courteous services efficiently in catering such needs.
\end{abstract}

Index Terms - Salient attribute, Customer Satisfaction, Hotel, Loyalty, and Mbeya Tanzania.

\section{INTRODUCTION}

Hotels Association of Tanzania (HAT) is concerned with growth development of the hotel sectors and tourism in general by improving the quality of product and services rendered to tourists and travellers, uplifting hotel profitability and cooperating with the relevant stakeholders in resolving issues of mutual interest(ATTA Report,2019). HAT is a

William L. Mboma, Assistant Lecturer, Department of Business and Entrepreneurship Studies (BES), National Institute of Transport

Doreen Ngaiza, Department of Business and Entrepreneurship Studies (BES), National Institute of Transport

Beatrice G. Yamlinga, Department of Business and Entrepreneurship Studies (BES)., National Institute of Transport

Bundala M. Kate, Assistant Lecturer, Department of Business and Entrepreneurship Studies (BES), National Institute of Transport member of TCT (Tourism Confederation of Tanzania) and ATTA.

In the mid-twentieth century, many production techniques and mass marketing changed the competitive landscape by increasing product availability for consumers. However, the purchasing process that allowed the shopkeeper and customer to spend quality time interacting with each other was also fundamentally changed. As a result, customers lost their uniqueness becoming an "account number." businessman lost track of their customers' individual needs as the market became full of product and service options. Many business today are striving to re-establish their network to new as well as existing customers to boost long-term customer loyalty (Chen and Popovich, 2003).

The customer today has the option to buy what he/she thinks he/she should and from whom, being in his/her best interest. Manufacturing development, technological improvement, cost reduction and excellent service facility are very important for any business, but their importance is only if the customer appreciates it.

\section{Mbeya Hotels Profile}

Mbeya is a city Council located in southwest Tanzania. According to 2012 census Mbeya urban has a population of 385,279.The main language is colloquial Swahili. English language is extensively taught in schools. The rains normally start in October and end around May, followed by a dry and cold spell between June and September. Mbeya can be reached by bus services along tarmac roads, or via the TAZARA railway line from the capital (approx. 600-miles, two overnight passenger trains per week). An airport is marked on maps, with a grass airstrip. Recently, constructed airport equipped with international standard facilities is already operational for passenger flights, cargo and other. It is known as Songwe international airport (ICAO: HTGW) (Mbeya Region Report, 2019).It is located approximately 10 $\mathrm{km}$ from the city center. Currently, there are four flights a week by Air Tanzania and Precision air (main carrier in Tanzania) with a plan to increase frequency to daily flights due to increased demand of air transport. Auric air is the other airline which ferries passengers to the city of Mbeya.

There are game watching safaris, and also trout fishing in the mountains to the south. There are efforts to widen tourism beyond animal and wild game viewing, which can best be done in Madibila and Rujewa. Mbeya is the best place in Tanzania for hiking and forest walking. This is aided by the cooler climate, friendly villages and pure clear water in the river catchments. Well-defined hiking trails have been 
established to enable hikers to reach the elevated areas and bio-diverse highlands, although the trails need to be properly mapped. For self-sufficient hikers, some of the best, and least known trekking in Africa is in the Poroto Mountains around the small town of Tukuyu. (Ibid)

Botanical excursions are also promoted, due to the presence of the natural flower garden at Kitulo. The recommended lodgings and hotels include: Beaco resort, Clam inn, Golden City Hotel, Mbeya Paradise Hotel, GR City Hotel, Mkulu Hotel, Diamond hotel, Mbeya Forest hill Hotel, Hill view Hotel, Mount Livingstone Hotel, Manyanya Hotel, the Karibuni Center, Mbeya Hotel, Holiday Lodge,Ifisi community center, Royal Tughimbe Hotel, FQ Hotel Mbeya, Malasi Rest House, Utengule Coffee lodge, BonakiHotel, Hotel Desderia, Southern City Hotel, N`gamba Coffee Lodge, Usungilo City Hotel.

Today hotel sectors has been recognized as a contributor of economic growth in the world, with producers and clients spread all over the world. The use of hotel facilities such as: room, restaurant, bar, nightclub or health club are no longer considered a luxury. For many people, these product and services have become an integral part of lifestyle. Moreover, in the last three decades, needs for and supply of hospitality services beyond that of the traditional services intended for travelers have escalated the growth of the hospitality industry globally, leading to intense competition in the market-place (Getty and Thompson, 2004). One of the greatest challenges facing hotel organizations today is the ever-growing volume and speed of competition. Competition has had major implications for the customer, providing increased choice, greater value for money and augmented levels of service (Ibid).

Additionally, there is small to differentiate between one hotel's products and services from another. Thus, it has become imperative for hotel organizations to gain a competitive advantage. There are two strategies most commonly used by hotel managers in order to gain a competitive advantage. These are low-cost leadership through price discounting and developing customer loyalty by providing unique benefits to customers (Ibid). Hotels that attempt to improve their market shares by discounting price, run the serious risk of having a negative impact on the hotel's medium- and long-term profitability. As a result, it is quality of service rather than price that has become the key to a hotel's ability to differentiate itself from its competitors and to gain customer loyalty. Getty and Thompson (2004) studied relationships between quality of lodging, satisfaction, and the resulting impact on customers' intentions to recommend the lodging to prospective customers. Their findings suggest that customers' intentions to recommend are a function of their perception of both their satisfaction and service quality with the lodging experience. However, satisfying customers alone is not enough, since there is no guarantee that satisfied customers will return to purchase. It is now becoming apparent that customer loyalty is significantly more important than customer satisfaction for success (Ibid). Numerous examples illustrate that it is important that the hotel industry develop customer loyalty, as opposed to relying solely on pricing strategies. Researchers have shown that a $5 \%$ increase in customer loyalty can produce a profit increase of $25 \%$ to $85 \%$ (Reichheld and Sasser, (2005). Hence, a dedicated focus on customer loyalty is likely to become a necessary prerequisite for the future survival of hotel organizations.

In the hotel industry, Customer Relationship Management (CRM) is more than the practice of collecting guest-centric data. It is the art of using historical, personal, and experiential information to personalize a guest's stay while generating incremental revenue opportunities. For instance, knowing a guest had a less-than-memorable experience in the hotel restaurant gives a one chance to win them back the next time they are in town (Microsoft, 2006). With the latest offerings in CRM, hoteliers can develop comprehensive guest profiles from reservation information and demonstrate to guests that the property is in touch with their needs, drive guest-centric data down to the transaction level, allowing employees and guest-facing technology to deliver greater value to the guest, generate a realistic profile on the spending and stay patterns of guests, allowing the property to create guest-centric marketing for increased loyalty and spending and the like.(Microsoft, 2006).

In summing up, the shift in the sales and marketing landscape requires the hotel companies to be as advanced as technology will allow in managing their customer relationships. "There is a big change from management of customer data to management of customer relationships". (Eurhotec, 2000) "Hotel companies must carefully consider how they store, track, analyze and act upon every aspect of their relationships with their guests and booking customers." The emphasis should be on using the data intelligently to predict consumer behavior, such as loyalty and usage patterns, and to use the customer knowledge to anticipate the customer needs or problems. This study attempted to assess the role of selected salient attributes on the customer satisfaction in the hotel industry the case being Mbeya city Hotel. The motivation for undertaking this study was a fact that there is no study which has assessed the topic under study specifically the hotel in Mbeya considering the fact that the city is growing up and attracting many people. Hence this study will fill that knowledgeable gap.

\section{LITERATURE REVIEW}

Modern marketers are rediscovering the ancient mantras for success in corporate world and blending them with contemporary marketing practices. Long term survival and competitive advantage can only be attained by establishing an emotional bond with the customers. A shift is taking place from marketing to anonymous masses of customers to developing and managing relationships with more or less well known or at least some identified customers (Gronroos, 2004).

\section{Theoretical Review}

\section{Service Quality Measurement Theory}

Service quality is vital to all organizations. Many service strategies are implemented to achieve customers' service quality expectations. Before each business makes a decision of which strategies are to be used, they have to know their 
strengths and weaknesses in order to make the right decision. A way to help the organizations determine their own situation is to measure the existing service quality provided to its customers. Several methods are used including customer satisfaction measurement, measurement by the critical incident technique, performance measurement, and attribute-based measurement. As the study focused on the attribute-based measurement, therefore expectation-perception approach (SERVQUAL) and only-performance approach (SERVPERF) were described. Soutar (2001) specified the most commonly used measurement of service quality was the SERVQUAL.

Schneider and White (2004) suggest that the perception-expectation measurement of service quality provides practical and research benefits. By using the perception-expectation measure, the practitioners knew which dimensions were needed to be improved. For the research benefit, the perception-expectation measure offered opportunities for the researchers to track the service quality.

According to Johns and Howard (1998), quality measurements only have operational value if they are able to indicate the ways in which service was or was not satisfactory. For service providers, the assessment of service quality is made during the actual delivery of the service. Much current research on service quality is rooted in expectancy-disconfirmation theory, which holds that customers perceive service quality as the difference between when the actual service performances exceeds expectations and negative when the opposite is the case.Parker and Mathews (2001) found that many studies supported the disconfirmation paradigm but others did not.

Lewis (1997) suggest that what can be measured are the differences between the abstractions. So if we can measure the difference between expectations and perceptions, which was defined as perceived quality, we can therefore determine the level of satisfaction. This concept was quite similar to the conceptual model of service quality suggested by Parasuramanet al (2005), which applied the expectancy disconfirmation theory. These authors had identified that there were five key discrepancies that can influence customer evaluations of service quality: Gap 1 was the gap between customer expectations and management's perceptions of those expectations, Gap $\mathbf{2}$ was the gap between management's perception of what the customer wants and specifications of service quality, Gap 3 was the gap between service quality specifications and delivery of the service, Gap 4 was the gap between service delivery and what the company promises to the customer through external communication and Gap 5 was the gap between customers' service expectations and their perceptions of service performance.

\section{A "GAPS" MODEL OF SERVICE QUALITY}

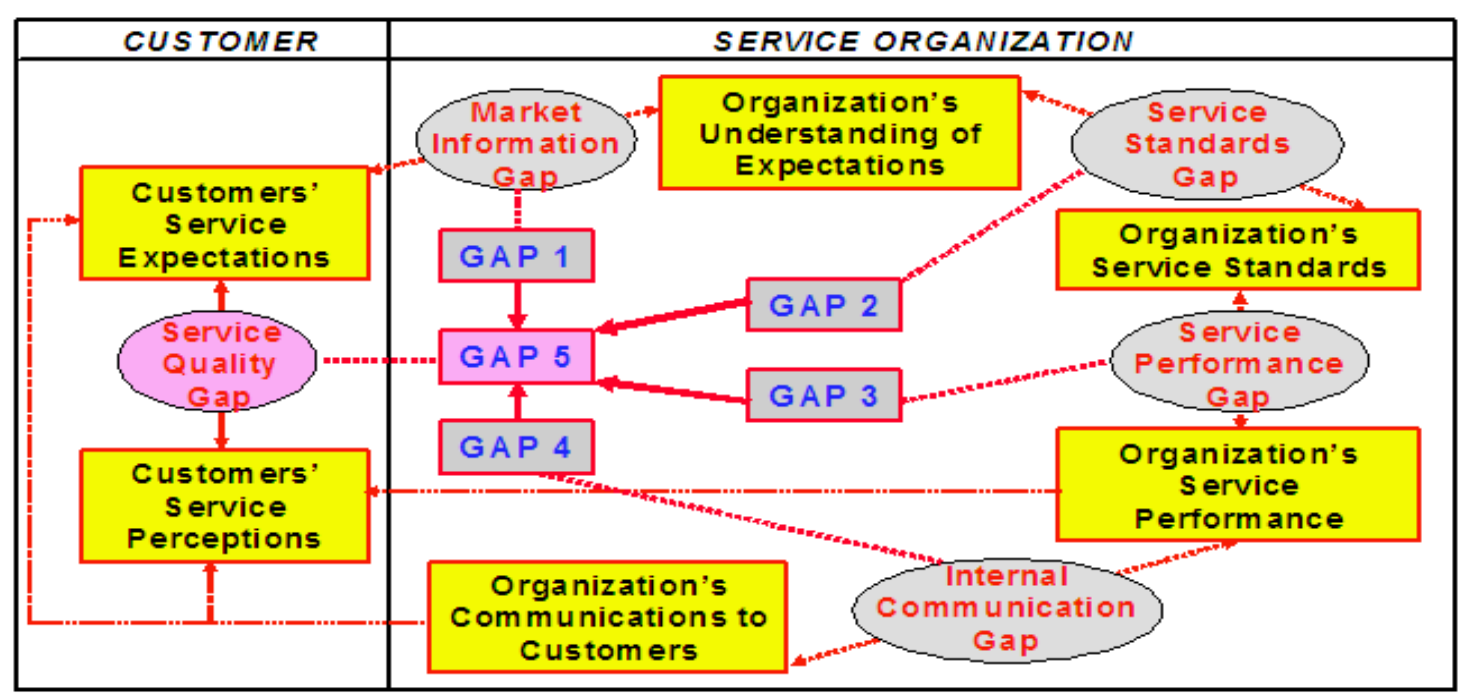

Source: A. Parasuramanetal (2005).

Figure 2.1: Gap Model of Service Quality

Zeithaml and Bitner (2003) state that in order to manage service quality, it was important to manage the gaps between expectations and perceptions on the part of management, employers and customers. The most important gap (Gap 5) was that between customers' expectations of service and their perceptions of the service actually delivered. So by referring to the gap model, it was noted that a service marketer must lessen the customer gap (Gap 5). In order to do so, the service provider must first try to lessen the other four gaps (Gap 1, 2 3 , and 4) within the organization that inhibit delivery of quality service, as each of these elements contribute towards the expectations and perceptions of customers. Serious action must be taken because how the customers, in these case hotel customers, perceive the level of service performance that 
meets their expectations will reflect the quality of service provided by the organization.

\section{Methodology}

Sample size of this study consisted of 5out of 20 hotels of which were operating in Mbeya City. The standard hotel criteria was based on sampling the 5 hotels and focused on 55 respondents which were owners, selected employees and customers from the sampled hotels in Mbeya City. This study used multiple methods. This was done intentionally because no single method is adequate in itself in collecting valid and reliable data on a particular problem both primary and secondary data collection was used. In this study, the questionnaire and interview data were analyzed by using a SPSS programme for windows 11.0. Before the detailed data analysis, questionnaire and interviews were thoroughly examined, variables coded and then imported into the SPSS software package. This process was done to all questionnaires and interview guides questions that were used during the field. This means that the information in the questionnaire and interviews were coded- that is converted into numerical codes and organized in a systematic,' machine-readable' manner. Therefore, the coding process helped to analyze the data into more details.

\section{RESUlt AND DisCUSSION.}

Atributes of customer relationship management on customer satisfaction

The respondents were asked to indicate the attribute of customer relationship management on customer satisfaction.

The findings are presented in Table 4.1 and Figure 4.1 below. Respondents in this area included customer.

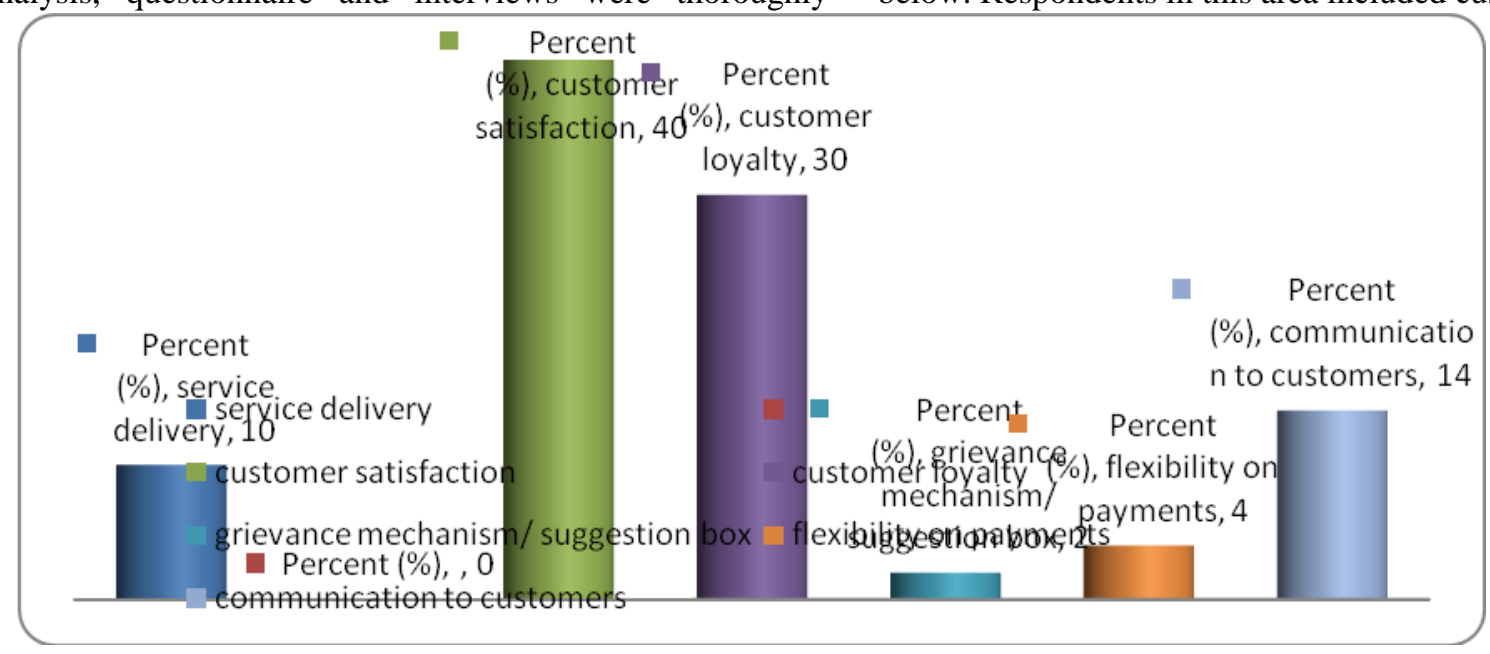

Figure 4.1: The attributes identified by customers

Source: Field Data, (2020)

Table 4.1: The attributes identified by customers

\begin{tabular}{|l|l|l|}
\hline Reasons Suggested by customers $(\mathbf{N}=\mathbf{5 0})$ & Frequency & Percent (\%) \\
\hline Service delivery & 5 & 10 \\
\hline Customer satisfaction & & \\
\hline Customer loyalty & 20 & 40 \\
\hline Grievance mechanism/ suggestion box & 15 & 30 \\
\hline Flexibility on payments & 1 & 2 \\
\hline Communication to customers & 2 & 4 \\
\hline Total & 7 & 14 \\
\hline
\end{tabular}

Source: Field Data, (2020)

Table 4.1 and Figure 4.1 above indicates that 20 (40\%), 15 (30\%), 7 (14\%), $5(10 \%), 2(4 \%)$ and 1 (2\%) of customers identified customer satisfaction, customer loyalty, communication to customers, service delivery, flexibility on payments and suggestion box as attributes of customer relationship management on service. This shows that customer satisfaction and customer loyalty are the key attributes in maintaining relationship with customers. The findings presented above concur with the compelling logic to the model, which has been dubbed the 'satisfaction-profit chain' (Anderson and Mittal, 2000). Satisfaction increases because customer insight allows companies to understand their customers better, and create improved customer value propositions. As customer satisfaction rises, so does customer repurchase intention (Anderson, 2004).This in turn influences actual purchasing behaviour, which has a significant impact on business performance.

In the same line, five owners of the hotels were also asked to indicate the attribute of customer relationship management on customer satisfaction. Table 4.2 and Figure 4.2 illustrate the findings. 
Table 4.2: The response identified by hotel owners

\begin{tabular}{|l|l|l|}
\hline Reasons Suggested by hotel owners $(\mathbf{N}=5)$ & Frequency & Percent $(\boldsymbol{\%})$ \\
\hline Service delivery & 1 & 20 \\
\hline Customer satisfaction & 2 & 40 \\
\hline Customer loyalty & 2 & 40 \\
\hline Total & $\mathbf{5}$ & $\mathbf{1 0 0}$ \\
\hline
\end{tabular}

Source: Field Data,(2013)

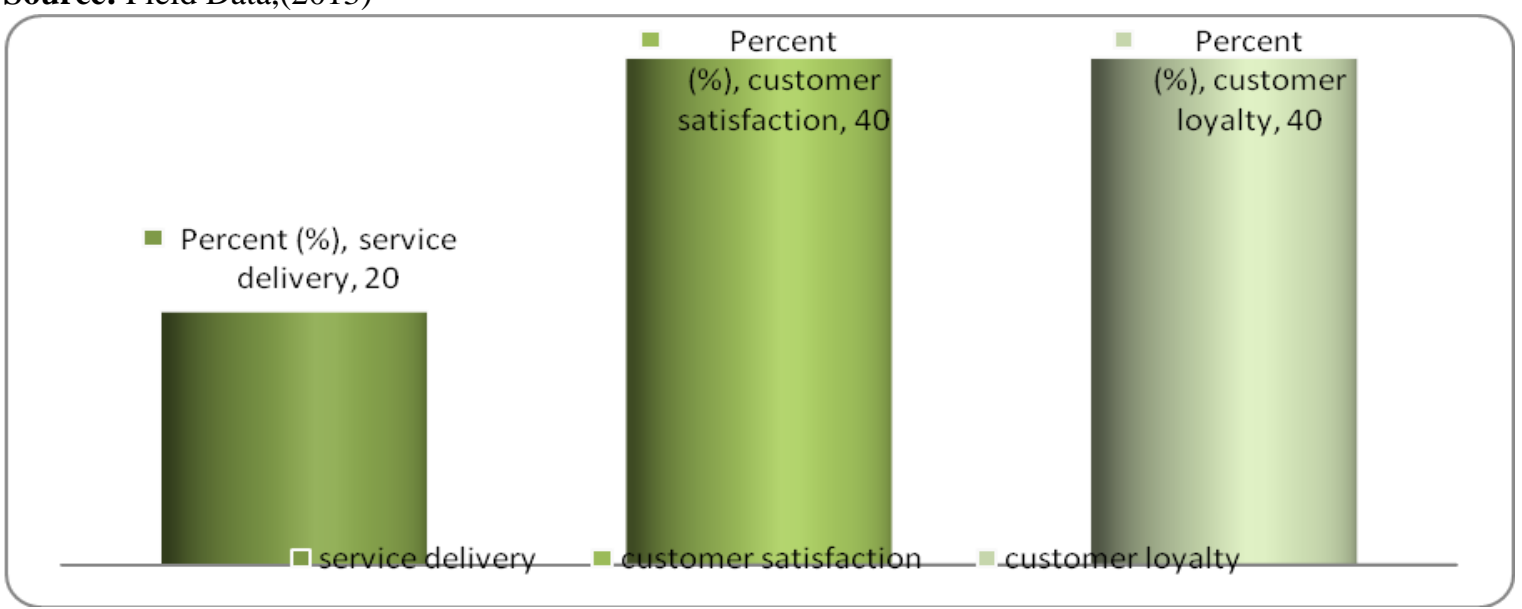

Figure 4.2: The response identified by hotel owners

Source: Field Data,(2020)

Table 4.2 and Figure 4.2 above indicates that 2 (40\%), 2 $(40 \%)$ and $1(20 \%)$ of interviewed hotel managers/owners identified customer satisfaction, customer loyalty and service delivery respectively as attributes of customer relationship management on service. This shows that customer satisfaction and customer loyalty are the key attributes in maintaining relationship with customers. The findings presented above correlate with the study done by Spreng and Mackoy (1996),Sureshchandaret al,(2003), Ribbinket al, (2004). Over the past few years there has been a heightened emphasis on service quality and customer satisfaction in business. Sureshchandar et al,(2003) identified that strong relationships exist between service quality and customer satisfaction while emphasizing that these two are conceptually distinct constructs from the customers' point of view.

This can be implied that a customer may estimate what the service performance was or may think what the performance

ought to be. If the service performance meets or exceeds customers and expectation, the customers was satisfied. On the other hand, customers are more likely to be dissatisfied if the service performance is less than what they have expected. As mentioned earlier, a greater number of satisfied customers will make the hotel business more successful and more profitable.

The service quality dimensions which relate to customer satisfaction

The respondents were asked to indicate the way service quality dimensions relate to customer satisfaction.

The findings are presented in the context of tangibility, reliability, responsiveness, assurance and empathy.

\section{Tangibility}

Respondents were asked to indicate the overall satisfaction of customers towards tangibility. The Study are presented in Table 4.3 and Figure 4.3 below. Respondents in this area included hotel owners and customers making a total of 55 respondents.

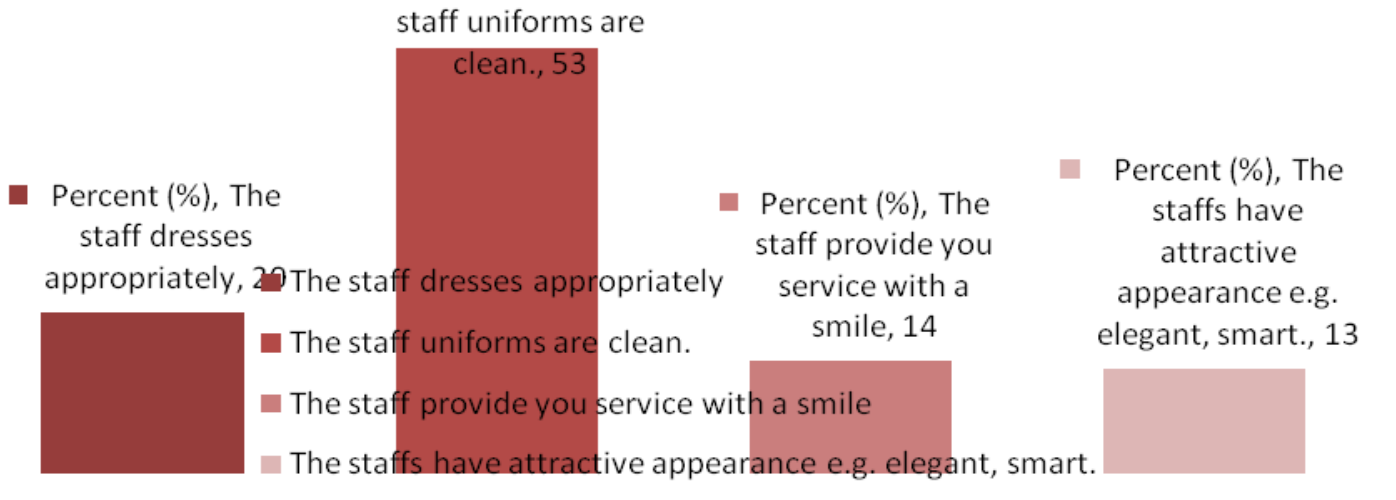

Figure 4.3: The dimensions identified by hotel owners and customers

Source: Field Data, ( 2020) 
Table 4.3: The dimensions identified by hotel owners and customers

\begin{tabular}{|l|c|c|}
\hline $\begin{array}{l}\text { Tangibility Dimensions Suggested by customers and hotel } \\
\text { owners }(\mathbf{N}=\mathbf{5 5})\end{array}$ & Frequency & Percent (\%) \\
\hline The staff dresses appropriately & 18 & 20 \\
\hline The staff uniforms are clean. & 47 & 53 \\
\hline The staff provide you service with a smile & 13 & 14 \\
\hline The staffs have attractive appearance e.g. elegant, smart. & 12 & 13 \\
\hline Total & $\mathbf{5 5}$ & $\mathbf{1 0 0}$ \\
\hline
\end{tabular}

Source: Field Data,( 2020)

Table 4.3 and Figure 4.3 above indicates that 47 (53\%), 18 (20\%), $13(14 \%)$ and $12(13 \%)$ of interviewed hotel owners/managers and customers identified the staff uniforms cleanliness, the staff dress appropriately, the staff providing service with a smile and the attractive appearance respectively as tangibles on customer satisfaction. tidiness of uniform and physical appearance of staff both received high ranking. This implies that when front office staff are well dressed and wear smart uniforms, their appearance impresses customers who feel more confident with hotel services. The findings presented correlate with the study done by

Dabholkaret al,(1996). The study found that tangibility dimension includes physical aspects such as the physical appearance of hotel services including the neatness of front office staff and professionalism of employees.

\section{Reliability}

Respondents were asked to indicate the overall satisfaction of perception towards reliability dimension. The findings are presented in Table 4.4 below. Respondents in this area included hotel owners and customers making a total of 55 respondents.

Table 4.4: The dimensions identified by hotel owners and customers

\begin{tabular}{|l|c|c|}
\hline $\begin{array}{c}\text { Reliability Dimensions Suggested by customers and hotel owners } \\
(\mathbf{N}=\mathbf{5 5})\end{array}$ & $\begin{array}{c}\text { Freque } \\
\text { ncy }\end{array}$ & Percent (\%) \\
\hline The staff provide service as promised & 54 & 55 \\
\hline The staff provide you accurate information & 17 & 19 \\
\hline The staff perform service for you correctly the first time & 6 & 7 \\
\hline The staff tell you exactly when service was provided & 13 & 14 \\
\hline Total & $\mathbf{5 5}$ & $\mathbf{1 0 0}$ \\
\hline
\end{tabular}

Source: Field Data, (2020)

Table 4.4 above indicates that 54 (55\%), 17 (19\%), 13 $(14 \%)$ and $6(7 \%)$ of the interviewed hotel owners and customers identified the staff provide service as promised, the staff provide accurate information, the staff perform service correctly the first time and the staff tell exactly when service was provided respectively as perception of reliability on customer satisfaction. This implies that staff provide service as promised receiving the highest score and may be because the receptionist provide service correctly the first time and keep their promises to customers. The findings presented correlate with the study done by Dabholkaret al,(1996).The study found that reliability dimension refers to the ability of the front office hotel staff to provide services dependably and accurately. Reliable service performance has to meet customer's expectation. Service must be accomplished on time, every time, in the same manner and without errors.

\section{Responsiveness}

Respondents were asked to indicate the overall expectation towards responsiveness dimension.

Findings are presented in Table 4.5 and Figure 4.4 below. Respondents in this area included hotel owners and customers making a total of 55 respondents.

- Percent $(\%)$, The staff respond to

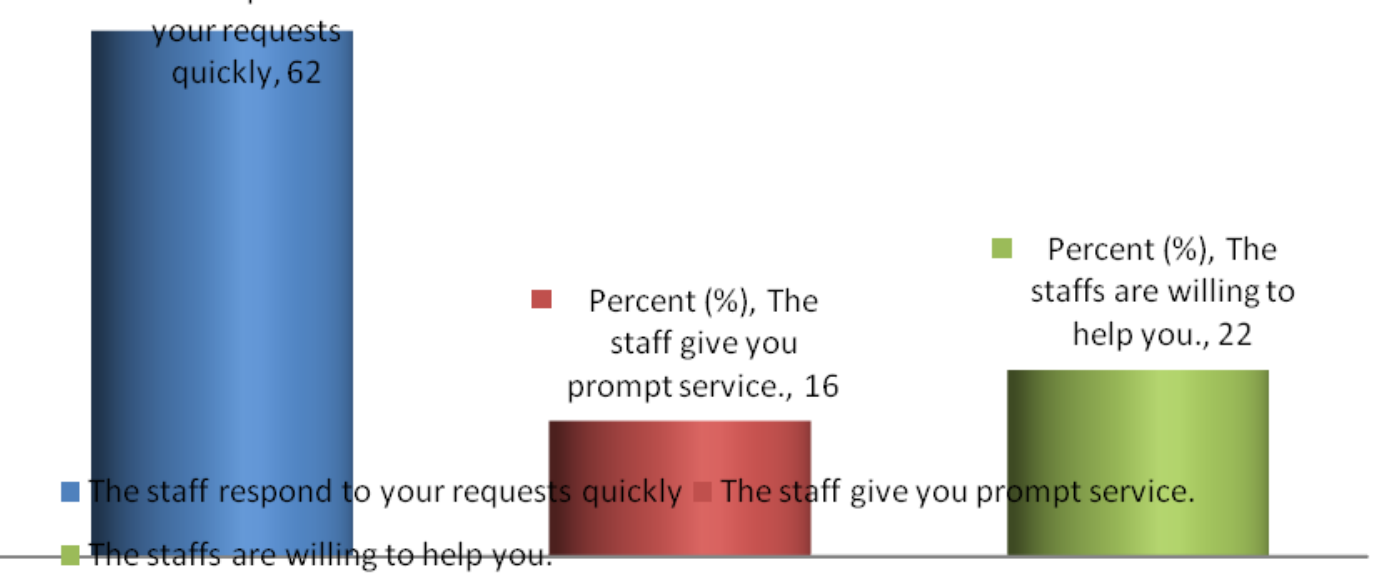


Figure 4.4: The dimensions identified by hotel owners and customers

Source: Field Data, (2020)

Table 4.5: The dimensions identified by hotel owners and customers

\begin{tabular}{|l|c|c|}
\hline $\begin{array}{l}\text { Responsiveness Dimensions Suggested by customers and hotel } \\
\text { owners (N=55) }\end{array}$ & Frequency & Percent (\%) \\
\hline The staffs respond to your requests quickly & 56 & 62 \\
\hline The staffs give your prompt service. & 14 & 16 \\
\hline The staffs are willing to help you. & 20 & 22 \\
\hline Total & $\mathbf{5 5}$ & $\mathbf{1 0 0}$ \\
\hline
\end{tabular}

Source: Field Data, (2020)

Table 4.5 and Figure 4.4 above indicates that 56 (62\%), 20 $(22 \%)$ and $14(16 \%)$ of interviewed hotel owners and customers identified the staffs respond to request quickly, staff were willing to help and the staffgave prompt service respectively as expectations towards responsiveness dimensions. This implies that customers are satisfied when they receive a quick response from the hotel staff. The findings presented concur with the study done by Zeithamlet al, (1988).The study found that responsiveness dimension involves willingness to help customers and provide prompt services. It is essential that front office hotel staffs are willing and able to help customers provide prompt service and meet customer's expectation.

\section{Assurance}

Respondents were asked to indicate the overall expectations towards assurance dimension. The findings are presented in Table 4.6 below. Respondents in this area included hotel owners and customers making a total of 55 respondents.

Table 4.6: The dimensions identified by hotel owners and customers

\begin{tabular}{|l|c|c|}
\hline $\begin{array}{c}\text { Assurance Dimensions Suggested by customers and hotel owners } \\
(\mathbf{N = 5 5})\end{array}$ & $\begin{array}{c}\text { Freque } \\
\text { ncy }\end{array}$ & $\begin{array}{c}\text { Percent } \\
(\boldsymbol{\%})\end{array}$ \\
\hline The staff have product Knowledge of the hotel & 43 & 48 \\
\hline The staff have the skills required to perform service & 4 & 4 \\
\hline The staff speak with you by using appropriate forms & 6 & 7 \\
\hline The staff are trustworthy & 27 & 30 \\
\hline The staff make you feel safe when staying at the hotel & 10 & 11 \\
\hline Total & $\mathbf{5 5}$ & $\mathbf{1 0 0}$ \\
\hline
\end{tabular}

Source: Field Data, (2020)

Table 4.9 above indicate that 43 (48\%), 27 (30\%), 10 (11\%), $6(7 \%)$ and $4(4 \%)$ of interviewed hotel owners and customers identified that staff had product knowledge of hotel, staff were trustworthy, staff made one to feel safe when staying at the hotel, staff spoke with the customer using appropriate forms and staff had skills required to perform services respectively as expectations towards assurance dimensions. This implies that product knowledge is the most important factor. Front office staff must have broad and deep knowledge, skills, capacity and experience. They must also be well versed in using advanced technology to improve their performances such as when making room reservations by computer. Most customers expect front office staff to make them feel safe when staying at the hotel. The findings presented concur with the study done by Parasuramanet al. (1991).The study that assurance dimension refers to the knowledge and courtesy of employees and their ability to inspire trust and confidence including competence, courtesy, credibility and security.

\section{Empathy}

Respondents were asked to indicate the expectations concerning empathy dimension. The findings were presented in Table 4.7 and Figure 4.5 below. Respondents in this area included hotel owners and customers making a total of 55 respondents. 


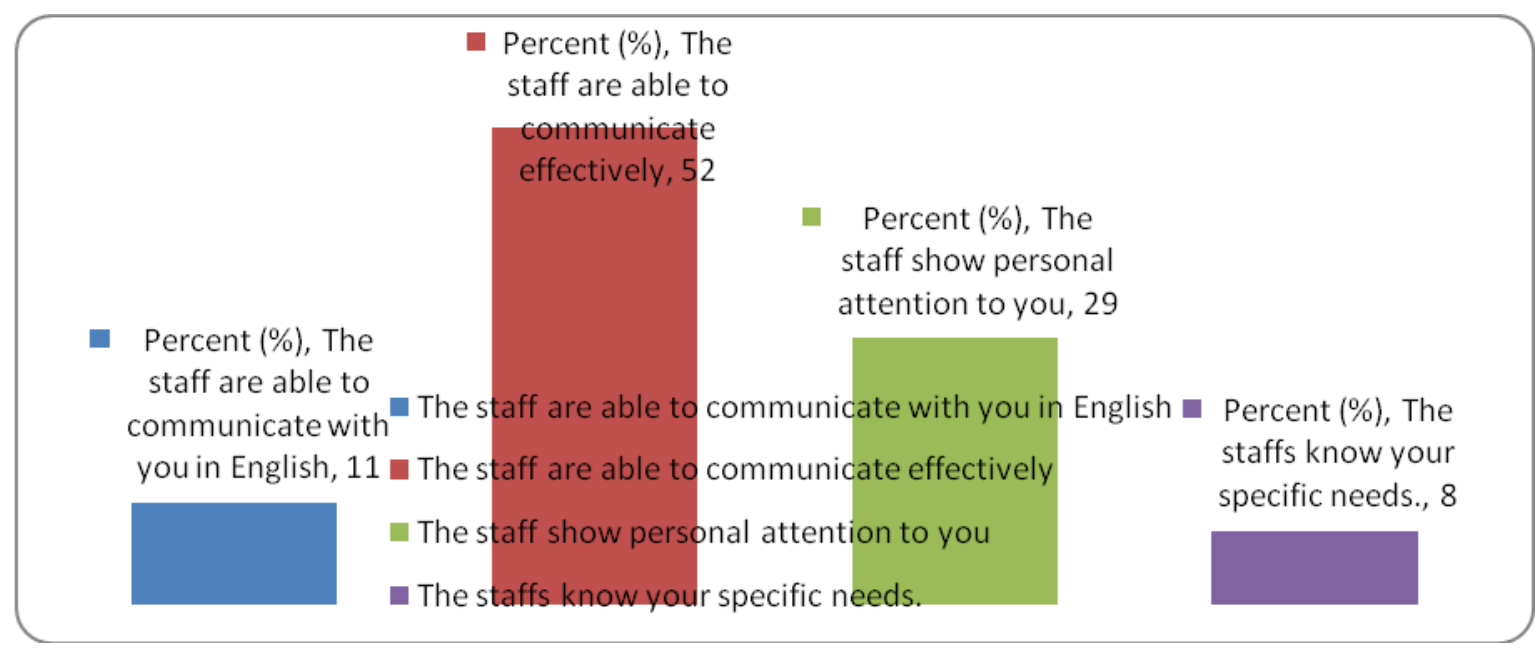

Figure 4.5: The dimensions identified by hotel owners and customers

Source: Field Data (2020)

Table 4.7: The dimensions identified by hotel owners and customers

\begin{tabular}{|l|c|c|}
\hline Empathy Dimensions Suggested by customers and hotel owners (N=55) & $\begin{array}{c}\text { Frequen } \\
\text { cy }\end{array}$ & $\begin{array}{c}\text { Percent } \\
(\mathbf{\%})\end{array}$ \\
\hline The staff are able to communicate with you in English & 10 & 11 \\
\hline The staff are able to communicate effectively & 47 & 52 \\
\hline The staff show personal attention to you & 26 & 29 \\
\hline The staffs know your specific needs. & 7 & 8 \\
\hline Total & $\mathbf{5 5}$ & $\mathbf{1 0 0}$ \\
\hline
\end{tabular}

Source: Field Data, (2020)

Table 4.7 and Figure 4.5 above indicate that 47 (52\%), 26 (29\%), $10(11 \%)$ and 7 (8\%) of interviewed hotel owners and customers identified that staff were able to communicate effectively, staff showed personal attention to the customer, staff were able to communicate in English and staff knew the specific needs respectively as expectations concerning empathy dimensions. This implies that effective communication is considered the most important expectation and front office staff represent the hotel and communication is vitally important. The findings presented correlate with the study done by Paige, (1977). He found that success of hotel work is based on effective communication. The front office deals with reservations, serves as the information centre and as the cashier. They must notify the housekeeping and kitchen divisions of guest information, and receive feedback. Effective communication among divisions in the hotel is one of the main factors that contribute to customer satisfaction which correlate with the study done by Crompton et al. (1991) which revealed that staff should make customers feel like they belong.

Overall dimensions of customer satisfaction towards service quality

Respondents asked to indicate the overall service quality dimension on customer satisfaction.

The findings are presented in Table 4.8 and Figure 4.6below. Respondents in this area included hotel owners and customers making a total of 55 respondents. 


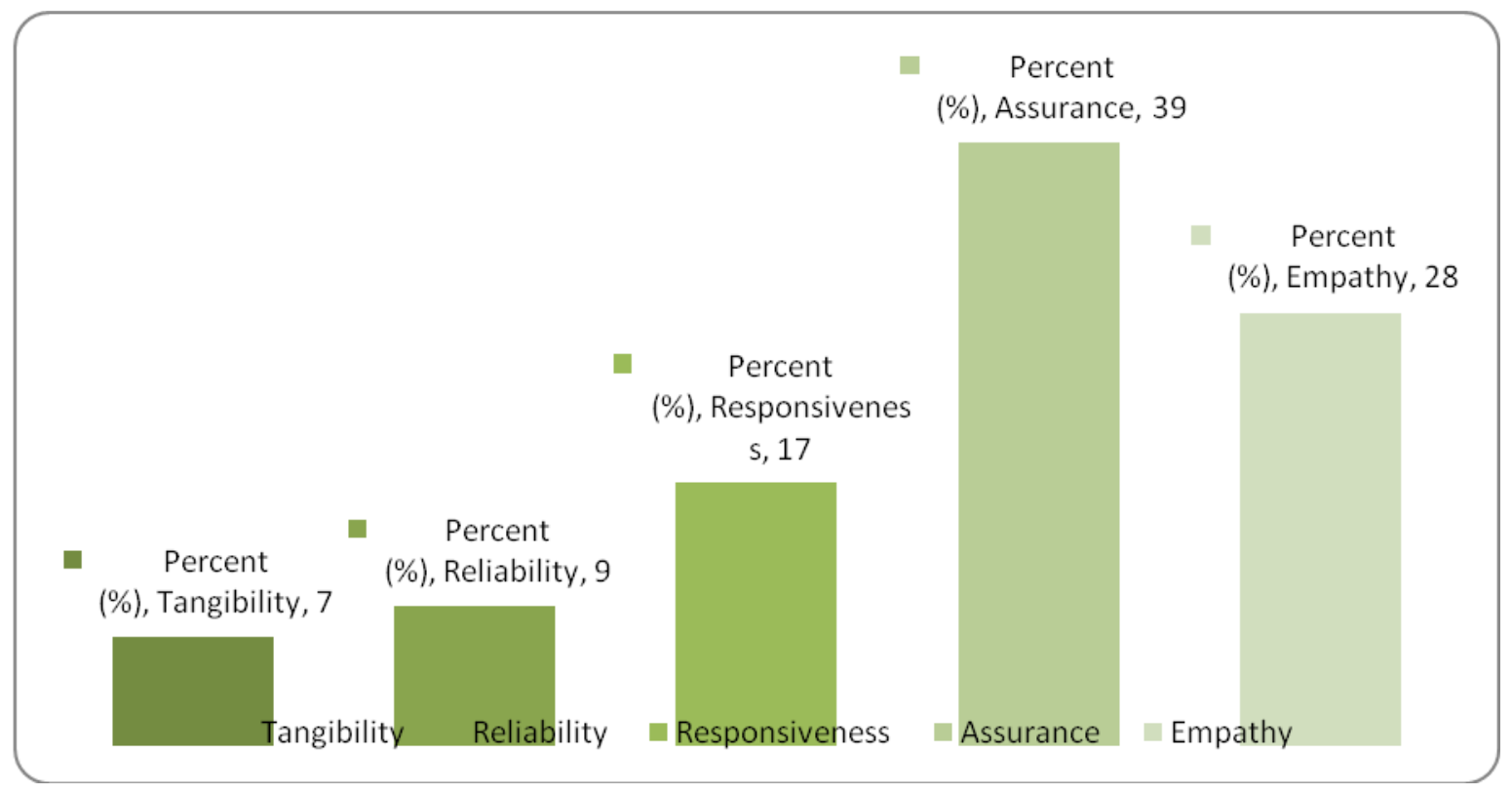

Figure 4.6: The Overall dimensions identified by hotel owners and customers

Source: Field Data, (2020)

Table 4.8: The Overall dimensions identified by hotel owners and customers

\begin{tabular}{|l|c|c|}
\hline Dimensions Suggested by customers and hotel owners (N=55) & Frequency & Percent (\%) \\
\hline Tangibility & 6 & 7 \\
\hline Reliability & 8 & 9 \\
\hline Responsiveness & 16 & 17 \\
\hline Assurance & 33 & 39 \\
\hline Empathy & 24 & 28 \\
\hline Total & $\mathbf{5 5}$ & $\mathbf{1 0 0}$ \\
\hline
\end{tabular}

Source: Field Data,( 2020)

Table 4.8 and Figure 4.6above reveal that 33 (39\%), 24 $(28 \%), 16(17 \%), 8(9 \%)$ and $6(7 \%)$ of interviewed hotel owners and customers identified assurance, empathy, responsiveness, reliability and tangibility respectively as service quality dimensions on customer satisfaction. The findings of customers satisfaction shows that assurance dimension was at the high level 33 (39\%). This implies that most customers expected the front office staff (especially the

cashier) to be trustworthy because they are responsible for the hotel expenses or collecting money from hotel guests.

The relationship between service quality attributes and customer satisfaction

Respondents were asked to indicate the relationship between service quality attributes and customer satisfaction. This was done using point likert scale. Table 4.11 provides the findings.

Table 4.9: Service quality attributes and customer satisfaction

\begin{tabular}{|l|l|l|l|l|l|}
\hline Ratings & Tangibility & Reliability & Responsive & Assurance & Empathy \\
\hline $\begin{array}{c}\text { Strongly } \\
\text { disagree }\end{array}$ & - & - & - & - & - \\
\hline Disagree & - & - & - & - & - \\
\hline Neutral & - & - & - & - & - \\
\hline Agree & 6 & 8 & 16 & - & 24 \\
\hline Strongly agree & - & - & - & 33 & - \\
\hline Total & $\mathbf{6}$ & $\mathbf{8}$ & $\mathbf{1 6}$ & $\mathbf{3 3}$ & $\mathbf{2 4}$ \\
\hline
\end{tabular}

Source: Field Data, (2020)

Table 4.9 above shows that $6(7 \%)$ agreed that service quality tangibility attribute relates positively to customer satisfaction. Overall, 33 (39\%) of assurance service quality attribute at least strongly agreed, on the other hand $8(9 \%), 16$ $(17 \%)$ and $24(28 \%)$ agreed that service quality attributes of reliability, responsiveness and empathy relates positively to customer satisfaction. This implies that assurance service quality attribute is essential for an organization survival and growth. This finding concurs with observation done by Gronroos (2001) that service quality represents a long-run, overall, evaluation which is different from customer satisfaction, a more short-term transaction specific judgment. 


\section{CONCLUSIONS}

Services marketing have been growing rapidly in twenty first century, while customer need for better high quality service is increasing. This is certainly the case at the Mbeya City hotels. To remain competitive, the hotel needs to analyse customer's expectation and perception towards the service quality of its front office staff. This study found out revenue growth (profit), number of customers and waiting time and resolved cases as the possible indicators that measure business performance in the study area.Hotel owners and customers accept that there is a great relationship between CRM and customer satisfaction They added that good quality services will satisfy the customers in the hotel industry. The findings have revealed that assurance dimension was at the high level, followed by empathy and responsiveness which determine the highest customer satisfaction. Most customers expected the front office staff (especially the cashier) to betrustworthy because they are responsible for the hotel expenses or collecting money from hotel guests.

\section{Recommendations}

Basing on conclusion that, the study objectives are; the extent business performance indicators relate to customer satisfaction in the hotel industry, the extent customer relationship management attributes relate to customer satisfaction of the hotel industry and the extent service quality dimensions relate to customer satisfaction of the hotel industry. It is recommended that:

Hotel owners/managers should make their clients happy and satisfied. As keys to the visitor's satisfaction driver, the Receptionist staffs are critical to the continued success of the hotel. Also the hotel management should focus on the main attributes that contributing towards customer satisfaction and final recommendation is the hotel management should analyze customer needs and expectations with this practice; more customers will be attracted and enjoy services that will be provided.

\section{REFERENCES}

[1] Aaker, D.A. and Jacobson, R. (1994) The financial information content of perceivedquality", Journal of Marketing, Vol. 58, 85 - 92

[2] Anderson, E.W. (2004), "Cross Strategy variation in customer satisfaction and retention", Marketing Letters,Vol. 5, Winter, pp. 19-30

[3] Anderson, E.W. \&Mittal,V. (2000), "Strengthening the satisfaction-profit chain", Journal of Service Research, Vol. 3(2), pp 107-120

[4] Batra, Rajeev and Olli T. Athola (1990), "Measuring the Hedonic and UtilitarianSources of Consumer Attitudes," Marketing Letters, 2 (2).

[5] Baumeister, H. (unknown), "Customer Relationship Management for SMEs", Available http://www.crm2day.com/library/EpFZEpykZkPeADiEcE.php, [last accessed on April 4, 2020.

[6] Bejou, D., Ennuw, C. and Palmer, A., (2008), "Trust, ethics and relationshipsatisfaction", Journal of Bank Marketing 16(4), pp 170.

[7] Bennett, R. (1996), "Relationship formation and governance in consumer markets: transactional analysis versus the behaviorist approach", Journal of Marketing Management, 12(12), pp. 417-436.

[8] Bhote, K.R (2006), "Beyond Customer Satisfaction to Customer Loyalty", New York: AMA Management Briefing.

[9] Bowen, J., Shoemaker, S. (2008), "Loyalty: a strategic commitment", Cornell H.R.A. Quarterly, 2, pp.12-25.

[10] Buttle, F. (2004), Customer Relationship Management: concepts and tools, Oxford: Elsevier Butterworth-Heinemann

[11] Carev, D (2008). Guest satisfaction and Guest Loyalty Study for Hotel IndustryDissertation, Master Science in Hospitality- Tourism Management, Rochester Institute of Management.
[12] Caruana, A., Money, A.H. and Berthon, P.R. (2000), "Service quality andsatisfaction-the moderating role of value", European Journal of Marketing, 34 (11/12), 1338- 53.

[13] Chen, J and Popovich, K. (2003). "Understanding customer relationship management $(C R M)$ : People, process and technology", Business Process Management Journal, Vol. 9 Iss: 5, pp.672 - 688

[14] Cohen, L, Manion, L, and McCoumick, R. (2001), Research Methods in education. London: RoutledgeFalmer.

[15] Cronin, J.J. Jr, Taylor, S.A (2002), "Measuring service quality: a re-examination andextension," Journal of Marketing, 56, pp.55-68.

[16] Dorrian, P. (1996), Intensive customer care: competitive strategies for South Africancompanies. Johannesburg, Zebra Press.

[17] Eroglu, Sergin A. and Karen A. Machleit (2000), "An Empirical Study of Retail Crowding: Antecedents and Consequences," Journal of Retailing, 66 (summer), 85 - 96

[18] Eurhotec, (2000), Customer Relationship Management: A Bold New Direction forHospitality Marketing, available at http://www.hospitalitynet.org/news customer relationship management in hotel industry, accessed on July 26, 2020

[19] Evans, J. R., \&Laskin, R. L. (1994), “The relationship marketing process: Aconceptualization and application", Industrial Marketing Management, 23(5), 439-452

[20] Farris, Paul W.; Neil T. Bendle; Phillip E. Pfeiffer; David J. Reibstein (2010) Marketing Metrics: The Definitive Guide to Measuring Marketing Performance. Upper Saddle River, New Jersey: Pearson Education.

[21] Fornier, S. (2004), “A Consumer-based Relationship Framework for Strategic BrandManagement", published $\mathrm{PhD}$ dissertation, University of Florida.

[22] Gale, B. (1992), Monitoring Customer Satisfaction and Market Perceived Quality, Worth Repeating Series, No. 922CS01, American Marketing Association, Chicago,IL.

[23] Gefen, D. (2002), "Customer loyalty in e-commerce", Journal of the Association for Information Systems, (3), 27-51.

[24] Getty, J.M. \& Thompson, K.N. (2004). The relationship between quality, satisfaction and recommending behavior in lodging decision. Journal of Hospitality and Leisure Marketing, 2(3), 3-22

[25] Grace, M. (2003), Customers or patients? British Dental Journal. 194(11)

[26] Gremler, D.D, Brown, S.W (2007), "Service loyalty: its nature, importance, and implications. Advancing service quality: a global perspective”, in Edvardsson(Eds), Quiz 5 Conference Processing, University of Karlstad, Sweden, pp.171-81

[27] Gronroos, C. (2001), Service Management and Marketing, 2nd edition, Chichester: John Wiley \& Sons Ltd.

[28] Gronroos, C. (2002), "Strategic Management and Marketing in the Service Sector",Helsinki: Swedish School of Economics and Business Administration.

[29] Gronroos, C. (2003), "Strategic Management and Marketing in the Service Sector”, Report No. 83-104, Marketing Science Institute, Cambridge, MA.

[30] Gronroos, C. (2004), “A service quality model and its marketing implications", European Journal of Marketing, 18, 36-44

[31] Gummesson, E. (2004), "Broadening and Specifying Relationship Marketing". Asia-Australia Marketing Journal, 2 (1), pp. 10-30.

[32] Hart, C.W., Heskett, J.L. and Sasser, W.E. (2000), "The profitable art of service recovery", Harvard Business Review, 68, pp. 148-56

[33] Hernon P. \&Whitwan, J.R. (2001). Understanding Customer Satisfaction Delivering satisfaction and service quality: A customer-based approach for libraries. American Library Association.

[34] Hoffman, K.D., \& Bateson, J.E.G. (2007). Essentials of services marketing. Fort Worth: Dryden Press.

[35] Jacoby, J., \&Kyner, D.B. (1973), "Brand loyalty versus repeat purchase behavior”, Journal of Marketing Research, 10(1), 1-9

[36] John, J. (2003). Fundamentals of Customer-Focused Management: Competing Through Service. Westport, Conn.: Praeger.

[37] Johns and Howard, (1998), "Customer Satisfaction, Loyalty, and the Trust Environment", in NA - Advances in Consumer Research Volume 25, eds. Joseph W. Alba \& J. Wesley Hutchinson, Provo, UT: Association for Consumer Research, Pages: 15-20.

[38] Johnston, R. and Fern, A. (2009), "Service recovery strategies for single and doubledeviation scenarios", The Service Industry Journal, 19(2), pp 69-82

[39] Julander, C, Magi, A, Jonsson, J, Lindqvist, A (1997), “Linking customer satisfaction to financial performance data", in Edvardsson (Eds),Advancing Service Quality: A Global Perspective", Sweden: University of Karlstad 
[40] Keaveney, S.M. (2005), "Customer switching behaviour in service industries: an exploratory study", Journal of Marketing, 58, pp 71-82

[41] Kell, S. (2001), Customer Care Evolution in the New Economy. [Online].http://www.summitcircuit.com/archive/et-O 10 1.html [2011, June.

[42] Koska, M.T. (1990), “High quality care and hospital profits: is there a link?'Journal of Hospitals. Vol.6,No.64, 21 - 28.

[43] Kotler P (2007). Marketing Management. Analysis planning implementation and control, prentice hall of India, New, Delhi.

[44] Kotler, P and Bowen, J (1996). Marketing for Hospitality and Tourism. Eaglewood Cliffs, NJ, Prince Hall.

[45] Kotler, P., (2000), Marketing Management. 10th edition New Jersey, Prentice-Hall.

[46] Lau, G. \& Lee, S. (1999). “Consumers' trust in a brand and link to brand loyalty". Journal of Market Focused Management, 4, 341-70

[47] Lewis, R.C. (2007). The measurement of gaps in the quality of hotel services. International Journal of Hospitality Management,

[48] Looy, B.V., Gemmel, P. and Dierdonck, R.V. (2003), "Services Management: An integrated approach", 2nd edition, Essex: Pearson Education Limited

[49] Lufthansa Airlines, advertisement in the Wall Street Journal, march 9, 2007

[50] Macintosh, G., \&Lockshin, L. S. (1997). "Retail relationships and loyalty: A multi-level perspective", International Journal of Research in Marketing, 14(5), 487-497.

[51] Min, H and Min, H (1997). Benchmark the Quality of Hotel Services: Managerial Perspectives, The international journal of Quality and Reliability Management 14(6)

[52] Moorman, C., Deshpande, R. \&Zaltman, G. (2003). "Factors affecting trust in market research relationships". Journalof Marketing, 57 (January), 81-101.

[53] Morgan, R.M. and Shelby D. H. (1994), "The Commitment-Trust Theory of Relationship Marketing", Journal of Marketing, 58, pp. 20-38

[54] McDonald, L. (2002), "Customer Relationship Management - An Overview, Available http://www.brillianceweb.com/betterwebdesign/tips_48.aspx, Accessed on July 30, 2020

[55] Normann, R (2001), "Service Management Strategy and Leadership in Service Businesses”, Chichester: John Wiley \& Sons Ltd

[56] M, And Andreson, $\mathrm{P}(\mathrm{Eds})$, Advances in Consumer Research, Provo, UT, pp. 218-22

[57] Oliver, R. L. (2000). A Cognitive Model of the Antecedents and Consequences of Satisfaction

[58] Parasuraman, A., Zeithaml, V.A. and Berry, L.L. (2005), “A conceptual model of service quality and its implications for future research", Journal of Marketing, 49, pp. 41-50

[59] Parasuraman, A., Zeithaml, V.A. and Berry, L.L. (2008), "SERVQUAL: A multiple-item scale for measuring consumers" perceptions of service quality", Journal of Retailing, 64(1), pp 22-37

[60] Parker, C., and Mathews, B.P. (2001) "Customer satisfaction: contrasting academic and consumers' interpretations", Marketing Intelligence \& Planning, Vol.19 Iss: 1, pp.38 - 44

[61] Patton, M. Q. (1997), How to Use Qualitative Methods in Evaluation. California: Sage Publications, Inc.

[62] Reichheld, F. (1996), The Loyalty Effect: The Hidden Force Behind Growth, Profits and Lasting Value, Harvard Business School Press, Boston, MA.

[63] Reicheld, F.F. and Sasser, W.E. Jr (1990), "Zero defections comes to services", Harvard Business Review, September-October, pp. 105-11.

[64] Ribbink, D., Van Riel, A.C.R., Liljander, V. \&Streukens, S. (2004). "Comfort your online customer: quality, trust and loyalty on the internet". Managing Service Quality, 14, 446-456.

[65] Rowley, J., \& Dawes, J. (2000), "Disloyalty: A closer look at non-loyal', Journal of Consumer Marketing. 17(6), 538-549.

[66] Schneider, B., \& Bowen, D. E. (1999), "Understanding customer delight and outrage”, Sloan Management Review, 41, pp. 35-46

[67] Selnes, F (2003), "An examination of the effect of product performance on brand reputation, satisfaction and loyalty", European Journal of Marketing, 27(9), pp.19-35.

[68] Soutar, G. (2001), "Consumer-Perceived Value: The Development of a Multiple Item Scale, ” Journal of Retailing, 77(2), 203-220.

[69] Spreng, R.A., Harrell, R.A. and Mackoy, G.D. (2005), "Service recovery: impact on satisfaction and intentions",Journal of Services Marketing, 9(1), pp 15-23

[70] Spreng, R.A. \&Mackoy, R. D. (1996). "An empirical examination of a model of perceived service quality and satisfaction". Journal of Retailing, 72 (2), 201- 14.
[71] Stanton, J., William, K. (2007), fundamentals of marketing $10^{\text {th }}$ edition MC GrawHill Inc. New York.

[72] Sugandhi, R.K. (2002), “Customer Relationship Management”, New Delhi: New age International Publishers

[73] Sureshchanndra, G. S., Rajendran, C. \&Anantharaman, R. N. (2003) "The relationship between service quality and customer satisfaction - a factor specific approach"Journal of Service Marketing, 16 (4), 363-379.

[74] Sutanto. J.E, (2009), "Dimension Quality of Service Influence Customer Satisfaction in the Hotel".

[75] Veal, A.J. (1997), Research Methods for leisure and tourism. A practical guide London Pitman.

[76] Wong O.M.A, Dean, A.M \& White, C.I (1999).Analyzing Service Quality in the Hospitality Industry-Managing service Quality, 9 (2), $136-143$

[77] Zemke, R. and Bell, C.R. (1990), Service Wisdom; Creating and Maintaining the Customer Service Edge, 2nd ed., Lakewood Books, Minneapolis, MN

[78] Zeithaml, V. A., \&Binter, M.J. (2003), "Service Marketing", New York: The McGraw-Hill Companies, INC.

[79] Zeithaml V.A., Parasuraman A., \& Berry L.L. (2000). Delivering quality service: Balancing customer perceptions and expectations. The Free Press, New York. NY. 